\title{
Postherpetic neuralgia - current facts and therapeutic possibilities
}

Nevralgia postherpetică - actualităţi şi posibilităţi terapeutice

Ana-Maria $\mathrm{CIOTI}^{1}$, Ana Maria Alexandra STĂNESCU ${ }^{1}$, Ioana Veronica GRĂJDEANU ${ }^{1}$, Daniela Oana TOADER ${ }^{2,3}$, Camelia Cristina DIACONU ${ }^{1,4}$

${ }^{1} \mathrm{CMI}$ „Dr. Grăjdeanu loana Veronica“, Bucureşti, România

2 Universitatea de Medicină şi Farmacie „Carol Davila“, Bucureşti, România ${ }^{3}$ Obstetrică-Ginecologie şi Neonatologie, INSC „Alessandrescu Rusescu“ - Clinica Polizu, Bucureşti, România

${ }^{4}$ Spitalul Clinic de Urgenţă, Bucureşti, România

\section{ABSTRACT}

Neuropathic pain in postherpetic neuralgia has an impact on important aspects of the patient's day to day life, lowering it's quality. Understanding the complex pathophysiological mechanisms of postherpetic neuralgia and assesing the patient's pain profile helps optimize the individualized, multimodal analgesic therapy that acts at different levels along the pain pathway. This paper is a review of the latest data in the literature regarding the pathophysiological mechanisms that lead to the emerging and evolution of postherpetic neuralgia and the up to date therapeutic possibilities.
\end{abstract}

Keywords: postherpetic neuralgia, neuropathic chronic pain, somatosensory profile, management

\section{REZUMAT}

Durerea neuropată din nevralgia postherpetică influențează aspecte importante ale vieții de zi cu zi a pacientului, scăzând calitatea acesteia. Cunoaşterea mecanismelor fiziopatologice complexe ale nevralgiei postherpetice şi stabilirea unui profil al durerii permit aplicarea unei terapii analgezice individualizate, multimodale, ce acționează la diferite nivele ale căilor de transmisie a impulsului dureros. Această lucrare este o trecere în revistă a ultimelor date disponibile în literatura de specialitate referitoare la procesele fiziopatologice ce stau la baza apariției şi evoluției nevralgiei postherpetice, dar şi a opțiunilor terapeutice de actualitate.

Cuvinte cheie: nevralgia postherpetică, durere neuropată cronică, profil somatosenzitiv, management 


\section{INTRODUCERE}

Nevralgia postherpetică (NPH) este o complicaţie debilitantă a infecţiei acute cu herpes zoster (AHZ), cu consecinţe medicale şi socioeconomice, respectiv depresie, limitarea activităţilor cotidiene, afectarea somnului, fatigabilitate şi scăderea calităţii vieţii, ce implică costuri notabile de îngrijire a sănătăţii. Durerea lancinantă este de cele mai multe ori refractară la tratament, reprezentând o provocare terapeutică pentru medici şi o povară pentru pacient.

NPH reprezintă complicaţia cea mai frecventă a afecţiunii determinate de herpesul zoster, afectând aproximativ 1 din 5 pacienţi (1). Herpesul zoster este mult mai frecvent în rândul vârstnicilor, iar probabilitatea ca durerea din $\mathrm{AHZ}$ să devină nevralgie postherpetică creşte brusc odată cu înaintarea în vârstă. NPH este definită ca durere neuropată severă ce persistă $\geq 3$ luni după apariţia leziunilor de herpes zoster, frecvent durând doar câteva săptămâni, alteori câteva luni sau chiar ani (2).

\section{FIZIOPATOLOGIA DURERII DIN INFECȚIA ACUTĂ CU HERPES ZOSTER (AHZ) ŞI DIN NEVRALGIA POSTHERPETICĂ (NPH)}

Virusul varicelo-zosterian, numit şi herpesvirus tip 3 (HHV-3), este un virus ADN din ordinul herpesvirusurilor, care, în primoinfecţie, este agentul cauzal al varicelei. AHZ apare ca urmare a reactivării virusului latent în ganglionii nervoşi spinali sau cranieni. Odată reactivat, virusul migrează de-a lungul traiectului nervos senzitiv, provocând leziuni neuronale, pentru a ajunge la dermatomul corespunzător la nivelul pielii (1). Simptomatologia prodromală (prurit, durere), ce precede apariţia leziunilor cutanate caracteristice, poate orienta diagnosticul într-o direç̧ie greşită. Persoanele afectate dezvoltă leziuni cutanate eritemato-veziculoase extrem de dureroase, cu distribuţie dermatomerică, ce se transformă în pustule, ulterior dezvoltă crustă hematică, iar în urma vindecării leziunilor rămân frecvent cicatrici sau modificări pigmentare $(1,2,3)$.

La baza durerii din nevralgia postherpetică stau unele procese fiziopatologice diferite faţă de cele implicate în durerea nociceptivă, uneori implicând impulsuri dureroase generate spontan, independent de acţiunea vreunui stimul (4). Cauza NPH nu a fost clarificată încă în mod concludent, dar se presupune că provine din procesele de reorganizare rezultate în cornul posterior, cu pierderea concomitentă a inhibării durerii, şi prin demielinizarea inflamatorie, cu deteriorarea secundară a fibrelor nervoase periferice (5). Multiple mecanisme au fost propuse pentru explicarea producerii durerii neuropate din nevralgia postherpetică. Printre acestea se numără „nociceptorul iritabil“ sau senzitizare primară, pierderea controlului inhibitor, senzitizare centrală, reorganizarea centrală şi, mai recent, generarea de impulsuri spontane la nivelul ganglionului senzitiv primar, în zone ce au căpătat rol de pacemaker ectopic $(4,6,7)$. 0 explicaţie pentru generarea de impulsuri ectopice este expresia anormală a canalelor de sodiu. Ipoteza pacemakerului ectopic aduce în discuţie o schimbare majoră în managementul terapeutic, respectiv posibilitatea utilizării unor analgezice ce acţionează doar asupra sistemului nervos periferic, evitând astfel reacţiile adverse generate de stimularea sistemului nervos central, precum somnolenţă, scăderea capacităţii de concentrare, vertij sau greaţă. Se lucrează în prezent la dezvoltarea unor stabilizatori de membrană care acţionează selectiv asupra subtipurilor de canale $\mathrm{Na}+$ prezente în neuronii SNP, dar nu şi în SNC $(6,7)$.

Un studiu realizat pe un lot de 198 de pacienţi a urmărit producţia de anticorpi anticitokine care ar putea determina o reactivare necontrolată, exagerată, a virusului varicelo-zosterian, generând, prin urmare, NPH secundară prin împiedicarea semnalizăriii imune. Acesta concluzionează că apariţia nevralgiei postherpetice reprezintă un proces complex, multifactorial, condus de factori genetici, de mediu sau dobândiţi, precum autoanticorpii anticitokine, dar nu aduce rezultate concludente, fiind necesare studii suplimentare. Prezenţa autoanticorpilor şi a declinului imun în rândul vârstnicilor reprezintă un fapt cunoscut, ceea ce sugerează probabilitatea existenţei unor autoanticorpi patogeni suplimentari, nerecunoscuţi, împotriva altor componente imune la subiecţii mai în vârstă, care pot creşte susceptibilitatea la NPH (8).

\section{NEVRALGIA POSTHERPETICĂ (NPH)}

Durerea asociată leziunilor din herpesul zoster poate fi clasificată în trei etape: durere acută, etapă ce durează până într-o lună; etapa de durere subacută, durere resimţită între 1 lună şi 3 luni de la vindecarea leziunilor cutanate, şi NPH, durere ce persistă mai mult de 90 de zile de la debutul erupţiei cutanate (2).

Nevralgia postherpetică se caracterizează adesea prin prezenţa durerii spontane cu caracter de arsură sau de înţepătură, ce asociază uneori prurit şi paroxisme dureroase. La nivelul dermatomului în cauză, sensibilitatea mecanică şi dureroasă sunt 
afectate, prezentând un răspuns exagerat la stimuli nocivi (hiperalgezie) sau stimuli nonnocivi (alodinie) (8). Aceste simptome pozitive pot fi însoţite de deficite senzoriale (semne negative), în special estomparea răspunsului la stimuli termici, sau de senzaţia de amorţeală şi parestezii $(7,10)$.

Evaluarea pacientului cu nevralgie postherpetică presupune o anamneză amănunţită, este de preferat ca pacientul să noteze într-un jurnal episoadele dureroase şi să înregistreze tipul şi intensitatea acestora, modul cum le afectează activităţile cotidiene, dar şi fluctuaţiile apărute de-a lungul timpului (8). Examinarea clinică presupune testarea sensibilităţii mecanice, termice şi dureroase la nivelul dermatomului afectat, dar şi comparativ, la nivelul dermatomului contralateral. Există numeroase teste senzoriale standardizate, cantitative, care evaluează spectrul de percepţii senzoriale anormale din durerea neuropată (11).

Un studiu a urmărit un lot de pacienţi cu NPH grupaţi în funcţie de fenotipul clinic, cei cu fibrele de tip $C$ normale cu funcţie senzorială conservată şi cei cu fibrele de tip $C$ deteriorate, cu pierdere senzorială. Pacienţii cu funcţie de fibră $C$ conservată sunt mai predispuşi să dezvolte semne de sensibilizare centrală, fapt demonstrat de un prag scăzut al durerii pentru sensibilitatea mecanică. Funcţia fibrelor de tip $C$ deteriorate se poate îmbunătăţi pe parcursul bolii, ceea ce susţine ideea dinamicii în timp a profilului dureros în nevralgia postherpetică (9). Alţi cercetători susţin ideea clasificării pacienţilor cu NPH în funcţie de anomaliile senzoriale din zona tegumentului, unde durerea este cea mai intensă, identificând profilul senzorial individual predominant şi, cel mai probabil, mecanismul de bază generator de durere (11). Cunoaşterea dezvoltării profilurilor somatosenzoriale în cursul bolii oferă posibilitatea optimizării tratamentului bazat pe mecanismul declanşării durerii $(9,11)$.

\section{TRATAMENT TOPIC}

Terapia topică poate fi utilizată în monoterapie ca tratament de primă linie pentru durerea uşoară sau în combinaţie cu medicamente sistemice, atunci când durerea este moderată sau severă (10).

Plasturele cu lidocaină $5 \%$ este cel mai studiat agent anestezic local pentru tratamentul nevralgiei neuropate localizate şi este utilizat ca terapie de primă linie, având ca posibilă reacţie adversă eritemul local (12). Lidocaina este un blocant nespecific al canalelor de Na ce reduce descărcările ectopice, ameliorând astfel durerea (13). De asemenea, plasturele în sine conferă protecţie împotriva stimulilor mecanici ce pot declanşa durere (12). Se pot utiliza până la 3 plasturi/zi, pe o durată de maximum 12 ore (10).

Capsaicina este un alcaloid ce se găseşte în diferite specii de ardei iute şi care se leagă de receptorul TRPV1 localizat la nivelul fibrelor nervoase de tip $A \delta$ şi C (14). Expunerea cronică la capsaicină suprastimulează şi desensibilizează receptorii, alterându-le funcţionalitatea (15). Spre deosebire de lidocaină, plasturele cu capsaicină $8 \%$ poate cauza mai multe reacţii adverse topice, precum senzaţie de arsură tranzitorie la nivelul zonei de aplicare, eritem local, prurit, edem local, papule sau uscarea tegumentului (12). Plasturele cu capsaicină $8 \%$ se aplică de către personalul medical pentru o durată de la 30 la 90 de minute. Anterior aplicării, se pot administra antialgic oral sau anestezic local pe întreaga suprafaţă ce urmează a fi acoperită de plasture. Tratamentul cu plasture cu capsaicină se poate repeta la 3 luni, în funcţie de persistenţa sau reapariţia durerii (10).

Olvanil este un analog sintetic al capsaicinei aflat acum în studiu, iar datele de laborator au indicat un efect analgezic mai mare prin desensibilizarea directă a canalelor TRPV1, cu mai puţine efecte secundare în aplicaţii topice. Rezultatele studiului susţin potenţialul substanţei sintetice Olvanil în dezvoltarea unor preparate topice care să trateze durerea neuropată fără reacţiile adverse nedorite cauzate de capsaicină (16).

\section{TRATAMENT SISTEMIC}

Gabapentin este analogul acidului gama aminobutiric (GABA) şi acţionează ca blocant al canalelor de $\mathrm{Ca}$, având efect în durerea neuropată printr-un mecanism neînţeles pe deplin. Printre reacţiile adverse se numără somnolenţa, oboseala, diplopia, nistagmusul, constipaţia şi xerostomia $(17,18)$. Au fost raportate şi disfuncţii sexuale, inclusiv disfuncţie erectilă, anorgasmie şi pierderea libidoului, efecte adverse care au dispărut complet la câteva săptămâni după încheierea tratamentului (19). Doza standard la adult pentru managementul durerii este de $300-600$ mg de 3 ori/zi până la max 1.800 mg zilnic (18).

Pregabalinul, asemenea gabapentinului, este analog GABA ce blochează canale de Ca de la nivelul SNC. Biodisponibilitatea de peste $90 \%$ face ca preparatul oral să aibă eficacitate crescută. Doza la adult pentru tratarea nevralgiei postherpetice este de $150-300 \mathrm{mg}$ de 2 sau 3 ori/zi. Se cunosc următoarele reacţii adverse: constipaţie, xerostomie, somnolenţă, dificultăţi de concentrare şi ver- 
tij (18). Date recente au evidenţiat o posibilă legătură între tratamentul cu gabapentin sau pregabalin şi instalarea fibrilaţiei atriale la pacienţii vârstnici (20).

\section{Antidepresive triciclice}

Antidepresivele acţionează ca analgezic în durerea neuropată prin inhibarea recaptării norepinefrinei $(21,22)$. Eficacitatea antidepresivelor triciclice în tratarea nevralgiei postherpetice a fost confirmată în numeroase studii, iar utilizarea lor ca tratament de primă linie este un consens internaţional. Reacţiile adverse asociate tratamentului cu antidepresive triciclice constau în efecte de tip anticolinergic, precum xerostomie, retenţie urinară, constipaţie, dar şi hipotensiune ortostatică şi cardiotoxicitate (23).

\section{Vitamina C}

Date din literatura de specialitate susţin faptul că administrarea de vitamina $C$ poate prezenta proprietăţi analgezice în unele afecţiuni clinice prin rolul acesteia de antioxidant, protejând astfel ţesuturile, inclusiv structurile nervoase de stresul oxidativ. Are, de asemenea, rol în procesul de sinteză al colagenului, neurotransmiţătorilor şi rol de cofactor în biosinteza aminopeptidelor opioide $(24,25,26)$. S-a observat că nivelul seric al vitaminei C scade în $\mathrm{AHZ}$ şi în NPH, iar administrarea intravenoasă de vitamina C 2,5-15 g zilnic sau la 2 zile, timp de 5-14 zile, ameliorează durerea şi reduce incidenţa NPH prin modularea nivelurilor serice de citokine, interleukină (IL)-6 şi IL-8 $(25,27)$.

\section{TRATAMENT INTERVENȚIONAL}

Pacienţii a căror durere este refractară la tratamentele noninvazive pot recurge la tratamente intervenţionale. Luând în considerare cât de invazivă este tehnica, profilul de siguranţă şi costurile, se recomandă iniţial intervenţii precum injectarea subcutanată a toxinei botulinice tip A, stimularea nervului periferic, stimularea nervilor electric transcutanat, blocul nervos periferic şi blocul ganglionului stelat, urmate de blocul paravertebral şi radiofrecvenţa pulsată $(28,29)$. În cazul persistenţei durerii de severitate crescută, se pot realiza stimularea măduvei spinării, injecţii intratecale cu metilprednisolon sau distrugerea ganglionului ră- dăcinii dorsale, având în vedere balanţa risc-beneficiu $(28,30)$.

\section{Acupunctura}

Acupunctura poate reduce intensitatea durerii, poate ameliora starea de anxietate şi poate îmbunătăţi calitatea vieţii. Electroacupunctura activează receptorii $\mu$-opioizi, scade nivelul chemoatractantului netrin-1, cu rol în creşterea axonală, transformând mediul de la nivelul ganglionului senzitiv spinal dintr-un mediu ce permite creşterea într-unul inhibitor, scăzând astfel înmugurirea axonală regenerativă şi durerea neuropată $(31,32)$.

\section{PREVENTIIA NEVRALGIEI POSTHERPETICE}

Cel mai eficient mod de a preveni nevralgia postherpetică este prin prevenţia herpesului zoster. Cel mai recent lansat vaccin împotriva herpesului zoster este Shingrix, un vaccin recombinant recomandat persoanelor cu vârsta > 50 ani, ce se administrează în două doze, la distanţă de 6 luni. S-a dovedit că oferă protecţie de peste $85 \%$ pe o perioadă de minim 4 ani împotriva herpesului zoster şi a complicaţiilor bolii, precum NPH (33).

Unele studii au demonstrat faptul că strategii preventive, precum tratamentul agresiv cu antivirale, asociat sau nu cu corticoterapia în faza acută a herpesului zoster, ar putea scădea incidenţa NPH $(6,34)$. De asemenea, tehnicile intervenţionale precum injecţiile epidurale, blocurile paravertebrale sau blocurile nervoase periferice asociate terapiei antivirale în faza acută scurtează durata şi severitatea durerii din AHZ, dar şi a incidenţei NPH (3).

\section{CONCLUZII}

Având în vedere că NPH este dificil de tratat, fiind deseori refractară la tratament, prevenţia AHZ are o importanţă capitală. În ciuda dovezilor ce susţin eficacitatea vaccinării cu Shingrix, rata de vaccinare a populaţiei este mică, cel mai probabil din cauza costului vaccinului, care nu face parte din schema naţională de vaccinări. Sunt necesare facilitarea accesului la vaccin şi investiţii financiare în vederea dezvoltării unor noi agenţi terapeutici pentru NPH, cu reacţii adverse minime.

Conflict of interest: none declared Financial support: none declared 


\section{BIBLIOGRAFIE}

1. Saguil A, Mercado M, Lauters R. Zoster and Postherpetic Neuralgia: Prevention and Management. Am Fam Physician 2017; 96(10):656-663.

2. Johnson WR, Alvarez-Pasquin MJ et al. Herpes zoster epidemiology, management, and disease and economic burden in Europe: A multidisciplinary perspective. Ther Adv Vaccines 2015;3(4):109-120.

3. Mishra S, Rasul A, Usmani H. Role of interventional treatment in acute pain of herpes zoster and prevention of postherpetic neuralgia. Indian J Pain 2019;33:7-10.

4. Motoc D, Turtoi NC et al. Durerea neuropată - particularităţi fiziologice şi fiziopatologice. Direcţii terapeutice. Revista Medicală Română 2011;58(1):21-27.

5. Hüning $S$, von Dücker L, Kohl WK et al. Therapy of herpes zoster and postherpetic neuralgia. The Dermatologist 2019;70:645.

6. Sirianni J, Ibrahim M et al. Molecular and Cell Biology of Pain. Progress in Molecular Biology and Translational Science 2015; 131:565-611.

7. Devor M. Rethinking the causes of pain in herpes zoster and postherpetic neuralgia: The ectopic pacemaker hypothesis. PAIN Reports 2018; 3(6):e702.

8. Bayat A, Burbel PD et al. Anti-cytokine autoantibodies in postherpetic neuralgia. Journal of Translational Medicine 2015; 13:333.

9. Gierthmuhlen J, Braig $O$ et al. Dynamic of the somatosensory system in postherpetic neuralgia. PAIN Reports 2018;3(6):e668.

10. Johnson RW, Rice ASC. Postherpetic Neuralgia. New England Journal of Medicine 2014; 371:1526-33.

11. Forstenpointner J, Rice ASC et al. Up-date on Clinical Management of Postherpetic Neuralgia and Mechanism-Based Treatment: New Options in Therapy 2018. Journal of Infectious Diseases 2018; 218(S2):S120-6.

12. DeLeón-Casasola OA, Mayoral V. The topical $5 \%$ lidocaine medicated plaster in localized neuropathic pain: A reappraisal of the clinical evidence. J Pain Res. 2016; 9:67-79.
13. Liu M, Wood JN. The roles of sodium channels in nociception: Implications for mechanisms of neuropathic pain. Pain Med 2011;12 Suppl 3:S93-9.

14. Fattori V, Hohmann MSN et al. Capsaicin: Current Understanding of Its Mechanisms and Therapy of Pain and Other Pre-Clinical and Clinical Uses. Molecules 2016;21:844.

15. Anand P, Bley K. Topical capsaicin for pain management: potential mechanisms of action of the new high-concentration capsaicin 8\% patch. Br J Anaesth. 2011; 107(4):490-502.

16. Alsalem M, Millns P, Altarifi A et al. Anti nociceptive and desensitizing effects of olvanil on capsaicin-induced thermal hyperalgesia in the rat. BMC Pharmacology and Toxicology 2016;17:31-41.

17. Sampathkumar P, Drage LA et al. Herpes Zoster (Shingles) and Postherpetic Neuralgia. Mayo Clin Proc. 2009; 84(3):274-280.

18. Viswanath O, Urits I et al. Membrane Stabilizer Medications in the Treatment of Chronic Neuropathic Pain: A Comprehensive Review. Current Pain and Headache Reports 2019; 23:3.

19. Hamed SA. Sexual dysfunctions induced by pregabalin. Clin Neuropharmacol. 2018; 41(4):116-2.

20. Ortiz de Landaluce L, Carbonell P et al. Gabapentin and Pregabalin and Risk of Atrial Fibrillation in the Elderly: A Population-Based Cohort Study in an Electronic Prescription Database. Drug Saf. 2018; 41(12):1325-31.

21. Max MB, Lynch SA et al. Effects of desipramine, amitriptyline, and fluoxetine on pain in diabetic neuropathy. New Engl J Med. 1992; 326:1250-1256.

22. Stefani C, Grajdeanu IV, Serban B, et al. Abordarea depresiei în practica medicului de familie. Revista Medicală Română 2019; LXVI(1):24-28.

23. Bruckenthal P, Barkin RL. Options for treating postherpetic neuralgia in the medically complicated patient. Therapeutics and Clinical Risk Management 2013; 9:329-340.
24. Carr AC, McCall C. The role of vitamin C in the treatment of pain: New insights. Journal of Translational Medcine 2017;15:77.

25. Chaitanya NCSK, Muthukrishnan A et al. An Insight and Update on the Analgesic Properties of Vitamin C. J Pharm Bioallied Sci. 2018;10(3):119-125.

26. Totan A, Greabu M, Stanescu II et al. Uric acid - history, present and future. Revista Medicală Română 2019;LXVI(2):150-152.

27. Jen-Yin Chen JY, Chu CC et al. Nutrient deficiencies as a risk factor in Taiwanese patients with postherpetic neuralgia. British Journal of Nutrition 2011;106:700-707.

28. Chen CC, Lao HC et al. Interventional Treatments for Postherpetic Neuralgia: A Systematic Review. Pain Physician 2019; 22:209-228.

29. Makharita MY. Prevention of Post-herpetic Neuralgia from Dream to Reality: A Ten-step Model. Pain Physician 2017; 20:E209-E220.

30. Codreau IF, Comănici VD, Stan IV, et al. Hemangiomatoza cutanată infantilă asociată cu hemangiomatoză hepatică multifocală - prezentare de caz. Practica Medicală 2018; 13,2(57):114-116.

31. Pei W, Zeng J. Is acupuncture an effective postherpetic neuralgia treatment? A systematic review and meta-analysis. Journal of Pain Research 2019; 12:2155-2165.

32. Li HP, Su W, Shu Y et al. Electroacupuncture decreases Netrin-1induced myelinated afferent fiber sprouting and neuropathic pain through $\mu$-opioid receptors. Journal of Pain Research 2019; 12:1259-1268.

33. The Centers for Disease Control and Prevention (CDC, 2018). Shingles (Herpes Zoster) Vaccine Safety.

34. Stefani C, Grajdeanu IV, Serban B et al. Importanţa cunoaşterii manifestărilor cutanate fiziologice în sarcină pentru managementul corect al afecţiunilor cutanate în sarcină. Practica Medicală 2019;14,1(64):26-29. 